\title{
Hubungan Pengalaman, Beban Kerja, Dan Kemampuan Perawat Dengan Tindakan Mandiri Di Rumah Sakit
}

\section{Relationship Of Experience, Workload And Ability Nurses Toward Quality Of Independen Nursing Action In Hospital}

\author{
Hani Tuasikal \\ Akademi Keperawatan Rumkit Tk III dr. J.A. Latumetten \\ Koresponding Penulis: \\ Corresponding author: hanituasikal@gmail.com
}

\begin{abstract}
Abstrak
Latar Belakang: Kualitas tindakan independen yang dilakukan perawat terhadap pasien mempengaruhi tingkat pasien. Implementasi tindakan independen perawat di ruangan masih rendah dibandingkan dengan tindakan delegasi dan kolaborasi. Perilaku perawat dalam memberikan tindakan independen dipengaruhi oleh faktor internal dan eksternal. Tujuan: Penelitian ini bertujuan untuk menguji hubungan pengalaman, beban kerja, kemampuan perawat terhadap kualitas tindakan keperawatan independen di Rumah Sakit. Metode: Penelitian ini menggunakan desain korelasi cross-sectional, yang dilakukan Maret 2017, dan melibatkan 165 perawat yang bekerja di ruang rawat inap sesuai dengan kriteria penelitian. Sampel berturut-turut diterapkan untuk menentukan ukuran sampel. Data dianalisis dengan bivariat dan multivariat regresi berganda menggunakan SPSS dengan tingkat signifikan $\mathrm{p}=$ 0,05 dan interval kepercayaan $=95 \%$. Hasil: Temuan menunjukkan hubungan yang signifikan antara Pengalaman, beban kerja, kemampuan $(p<0,05)$ dengan kualitas tindakan keperawatan independen. Hasil analisis multivariat menunjukkan hubungan yang signifikan antara pengalaman dengan $r=0,069$ (CI95\%: 0,385-0,449: $p=0,097)$, beban kerja $r=0,006$ (CI95\%: 57,60-66,70; $\mathrm{p}=0,011)$ dan kemampuan $\mathrm{r}=0,150$ (CI95\%: 139,65-142,95; $\mathrm{p}=$ $0,023)$ dan kualitas tindakan keperawatan independen $(\mathrm{R}$ square $=0,645)$. Variabel terkuat terkait dengan kualitas tindakan keperawatan independen adalah kemampuan perawat $(\mathrm{r}=$ 0,150). Kesimpulan: Kualitas tindakan keperawatan inpenden di ruang rawat inap terkait dengan Pengalaman, beban kerja, dan kemampuan keperawatan. Faktor dominan adalah kemampuan perawat.
\end{abstract}

Kata kunci: Kualitas tindakan keperawatan inpenden, pengalaman, beban kerja, kemampuan perawat

\begin{abstract}
Abstrak
Background: Quality independent actions undertaken nurse to the patient affect the level of the patient.The implementation of the nurse's independent actions in the room is still low compared to the delegation and collaboration actions. The behavior of nurses in providing independent actions isinfluenced by internal and external factors.Objective: This study aims to examine the relationships of experience, workload, ability nurses toward quality of independent nursing action in Hospital. Methods: This study employed a cross-sectional
\end{abstract}


Journal of Healthcare Technology and Medicine Vol. 6 No. 1 April 2020

Universitas Ubudiyah Indonesia

e-ISSN : 2615-109X

correlation design, which was conducted Maret 2017, and involved 165 nurses work in the inpatient ward according to research criteria. A consecutive sampling was applied to determine sample size. Data were analyzed by bivariat and multivariat multiple regression using SPSS with significant level $p=0.05$ and confidence interval $=95 \%$. Results: Findings showed significant relationships between Experience, workload, ability $(p<0,05)$ with quality of independent nursing action. The results of multivariat analysis showed significant relationships between experience with $r=0,069$ (CI95\%: 0,385-0,449:p=0,097), workload $r=0,006$ (C195\%:57,60-66,70; $p=0,011)$ and ability $r=0,150$ (C195\%:139,65-142,95; $p=0,023)$ and quality of independent nursing action $(R$ square $=0.645)$. The strongest variable related to quality of independen nursing action was ability of nurses $(r=0.150)$. Conclusions: Quality of inpenden nursing action at inpatien room related to with Experience, workload, and ability of nursing. The dominant factor is ability of nursing.

Keyword: Quality of inpenden nursing action, experience, workload, ability of nurse

\section{PENDAHULUAN}

Tindakan mandiri keperawatan merupakan tindakan yang dilakukan oleh seorang perawat secara mandiri. Tindakan ini berdasarkan ilmu pengetahuan dan kemampuan yang dimiliki. Tindakna mandiri yang dilakukan untuk memenuhi kebutuhan bio-psiko-sosio dan spiritual pasien di rumah sakit. ${ }^{1}$ Tindakan mandiri memberikan kuntribusi terbesar terhadap pelayanan keperawatan. Tindakan yang diberikan secara optimal akan menghasilkan kualitas tindakan yang mampu meningkatkan kepuasan pasien, mempercepat kesembuhan pasien serta meningkatkan keselamatan. Oleh karena itu, tindakan mandiri harus dilakukan oleh setiap perawat secara optimal dan berkualitas untuk menyembuhkan pasien.

Perawat di ruang rawat inap memiliki tanggung jawab yang lebih besar karena memiliki waktu yang lebih lama untuk merawat pasien. ${ }^{2}$ Tenaga kesehatan yang waktunya paling lama dengan pasien adalah perawat karena jumlahnya antara 50-60\%, memiliki jam kerja 24 jam melalui penugasan shift dan merupakan tenaga kesehatan yang paling dekat dengan pasien. ${ }^{3,4} \mathrm{Hal}$ ini dikarenakan banyak tindakan yang akan diberikan kepada pasien dengan berbagai kondisi dan kebutuhan yang dipenuhi oleh perawat untuk mempercepat kesembuhan pasien. Akan tetapi, ditemukan banyak tindakan mandiri yang tidak dilakukan oleh perawat di ruang rawat.

Tindakan mandiri yang tidak dilakukan atau tidak terselesaikan akan memberikan dampak buruk terhadap proses pelayanan keperawatan salah satunya adalah ketidakpuasan pasien terhadap pelayanan yang diberikan. Dari 12 kegiatan yang dilakukan oleh perawat hanya sebagian yang dilaksanakan dan sebagiannya tidak dilaksanakan selama satu shift. 5,67 Hasil penelitian yang dilakukan di Amerika didapatkan bahwa pada Instalasi bedah 56\% pasien kurang puas dengan tindakan yang diberikan oleh tenaga keperawatan, di Instalasi 
Journal of Healthcare Technology and Medicine Vol. 6 No. 1 April 2020

Universitas Ubudiyah Indonesia

e-ISSN : 2615-109X

non bedah didapatkan $53,3 \%$ pasien kurang puas dengan penjelasan tindakan yang dilakukan perawat, di Instalasi anak $57.2 \%$ pasien tidak puas dengan pelayanan yang diberikan oleh perawat dan di Instalasi Ambun pagi didapatkan 14,7\% pasien kurang puas dengan pelayanan keperawatan di ruangan. ${ }^{3,7}$

Rumah sakitDi Inggris terdapat banyak tindakan mandiri keperawatan yang tidak dilakukan oleh perawat yang berimbas pada kualitas tindakan. Kejadian ini ditemukan di rumah sakit Nasional Health Service bahwa tindakan mandiri seperti perawatan mulut, memberikan pendidikan kesehatan kepada pasien dan pemberian makanan oral tidak dilakukan oleh perawat. Tindakan yang tidak dilakukan dinilai sebagai salah satu kegagalan dalam meningkatkan keselmatan pasien. ${ }^{8}$

Hasil wawancara dengan perawat di Rumah Sakit X di Ambon didapatkan bahwa beberapa perawat masih sulit membedakan antara tindakan mandiri perawat dan tindakan medis. Beban kerja yang tinggi membuat perawat cenderung melakukan tindakan rutinitas yang lebih mengarah kepada tindakan medis dan kegiatan administrative. Hal ini didukung dengan hasil observasi dari 10 tindakan mandiri hanya 4 tindakna yang dilakukan rutin oleh perawat di rumah sakit. Tindakan yang tidak dilakukan diantaranya membantu memberikan makan kepada pasien, mendengarkan keluahan dari pasien, melakukan mobilisasi posisi pada pasien dan mendiskusikan dengan pasien terkait dengan kondisi pasien.

Dampak dari tindakan mandiri yang tidak dilakukan dapat berakibat pada meningkatnya angka dekubitus yang terjadi pada salah satu rumah sakit X di Ambon tahun 2015 yaitu 11,8\%. Dengan meningkatnya angka decubitus akan berdampak terhadap mutu pelayanan keperawatan yang diberikan kepada pasien yang secara tidak langsung menurunkan kualitas tindakan mandiri perawat. Hal ini didukung dengan penelitian yang dilakukan oleh Kalisch 2014 bahwa tindakan mandiri yang tidak dilakukan akan akan berdampak terhadap luka tekan pada pasien, infeksi baru dan pasien jatuh. ${ }^{9}$ Kurangnya kemampuan perawat dalam memonitoring pasien dengan tingkat ketergantungan total care yang membutuhkan tindakan perubahan posisi setiap 2 jam sekali.

Ketidakmampuan perawat dalam melakukan tindakan mandiri keperawatan memberi dampak terhadap ketidakpuasan pasien pada pelayanan keperawatan. Menurut penelitian Agus tahun 2008 mengungkapkan bahwa pasien mengatakan kualitas pelayanan yang diterima masih rendah sehingga kepuasan yang dirasakan pasien juga masih rendah. ${ }^{10} \mathrm{Hal}$ ini akan mempengaruhi persepsi pengguna pelayanan kesehatan bahwa perawat tidak mampu melakukan tindakan mandiri yang mana merupakan suatu identitas dari perawat itu sendiri. Apabila hal ini tidak segera diatasi akan berimbas kepada profesionalisme perawat dalam 
Journal of Healthcare Technology and Medicine Vol. 6 No. 1 April 2020

Universitas Ubudiyah Indonesia

e-ISSN : 2615-109X

melakukan tindakan keperawatan di rumah sakit. Ini sesuai dengan penelitian dari Novitra tahun 2004 yang mengatakan bahwa profesionalisme perawat menjadi unsur yang penting dalam upaya peningkatan status kesehatan pasien. ${ }^{11,8}$

Kualitas dari tindakan mandiri sangat dibutuhkan untuk dapat meningkatkan kesembuhan pasien. Tindakan mandiri yang diberikan secara optimal dapat memberikan gambaran kepada pasien agar mengetahui mana tindakan keperawatan dan tindakan medis yang dilakukan untuk menyembuhkan pasien. ${ }^{12,13}$ Dengan pasien mengetahui perbedaan antar tindakan yang diberikan oleh perawat, pasien akan lebih mengerti dan memahami bahwa tindakan keperawatan dapat menyembuhkan tidak hanya dengan pemberian obatobatan.

Berdasarkan hasil penelitian yang dilakukan oleh Andriani 2016 didapatkan bahwa sebagain besar perawat di ruangan tidak melakukan tindakan keperawatan seperti perawatan rambut $(66,9 \%)$, perawatan gigi dan mulut $(78,2 \%)$, toileting $(66,2 \%)$ dan perawatan perineum $(84,2 \%){ }^{14}$ Dengan hasil ini mengindikasikan bahwa pelaksanaan personal hygiene tidak baik di ruang. Apabila hal ini dibiarkan terjadi secara terus menerus akan berakibat terhadap meningkatnya angka LOS pada pasien, ketidakpuasan pasien dan menurunnya selft care pasien. ${ }^{7,15}$

Menurut penelitian Susanti tahun 2013 bahwa terdapat hubungan yang signifikan antara pengalaman dengan motivasi dalam pemenuhan kebutuhan diri pasien di RS dr. H. Koesnadi Bondowoso. Pengalaman yang didapat oleh perawat yakni dalam merawat pasien dengan berbagai jenis diagnosa keperawatan. ${ }^{12}$ Pengalaman yang ada pada perawat akan memberikan gambaran yang jelas untuk melaksanakan tindakan mandiri dibandingkan yang tidak memiliki pengalaman. Tidak hanya pengalaman akan tetapi, beban kerja juga memiliki hubungan dengan kualitas kinerja karyawan

Beban kerja perawat berhubungan erat dengan kinerja perawat di ruamh sakit. Salah satu kinerja perawat di rumah sakit yakni melakukan tindakan mandiri perawat. Tingginya beban kerja berdampak terhadap kulitas tindakan yang diberikan. Hal ini terjadi karena banyaknya tindakan yang dibebankan kepada perawat baik medis maupun administrasi. Tingginya beban kerja dipengaruhi oleh kurangnya tenaga perawat dibandingkan dengan jumlah pasien serta tingkat ketergantungan pasien. ${ }^{17}$ Oleh karena itu, berdasarkan penjelasan diatas maka peneliti tertarik untuk meneliti tentang hubungan antara kemampuan, pengalaman dan beban kerja dengan kualitas tindakan mandiri.

\section{METODE PENELITIAN}


Journal of Healthcare Technology and Medicine Vol. 6 No. 1 April 2020

Universitas Ubudiyah Indonesia

e-ISSN : 2615-109X

Design

Penelitian ini menggunakan desain cross sectional dengan teknik pengumpulan data menggunakan studi observasional untuk menghubungkan dua atau lebih variabel dependen dengan variabel independen.

\section{Sample size}

Sampel yang digunakan dalam penelitian ini adalah perawat yang tersebar di 14 ruang rawat inap RSUD dr. M. Haulussy Ambon yang terdiri dari Ruang Paviliun, Bedah Wanita, Bedah Pria, THT,Kulit kelmain, Cendrawasih, Ruang Kanak-kanan, ruang interna wanita, ginekology, neonatologi, wetar, paru, ruang interna laki dan neurologi. Besar sampel berjumlah 165 perawat yang dihitung sesuai dengan rumus multivariate regresi liner dan disesuaikan dengan jumlah varibel independen. Teknik pengambilan sampel dengan menggunakanprobability sampling. Sampel dalam penelitian ini sesuai dengan kriteria inklusi; (1) perawat yang bekerja di ruang rawat inap, (2) perawat pelaksana. Sedangkan kriteria eksklusi (1) perawat yang mengikuti pendidikan dan (2) perawat yang sedang cuti.

\section{Instrument}

Variabel kemampuan menggunakan kuisioner kemampuan yang dikembangkan oleh Hersey \& Blanchardmenggunakan skala likert yang terdiri dari 35 item pernyataan dengan pilihan jawaban 1;sangat tidak setuju, 2;tidak setuju, 3;kurang setuju,4;setuju, 5;sangat setuju. Hasil ukur yang didapatkan dengan nilai maksimal 175 dan minimal 35. Variabel beban kerja menggunakan kuisioner NASA-TLX yang dikembangkan oleh Sandra G Hart \& Lowell E Staveland berisi 6 indikator beban kerja menggunakan rating scale dengan nilai tertinggi 21 dan terendah 1 . Hasil ukur yang digunakan untuk skor maksimal 126 dan minimal 6.Untuk variabel pengalaman menggunakan 1 item pertanyaan. Tindakan mandiri dilakukan dengan mengobservasi 14 tindakan keperawatan yang meliputi Activity of daily livings, carring dan support, rehabilitasi dan monitoring.

Kusioner kemampuan dan beban kerja telah di translate kedalam bahasa indonesia oleh ahli bahasa, setelah mendapatkan ijin untuk menggunakan dan memodifikasi kuisioner. Kuisioner dimodivikasi kemudan dilakukan uji validitas. Hasil uji validitas kuisioner kemampuan bahwa semua item dinyatakan valid dengan nilai $r$ terendah 0,383 dan tertinggi 0,795 nilai $r$ tersebut $>$ dari nili $r$ tabel $=0,361$ serta nilai reliabilitas 0,963 . Untuk kuisioner beban kerja didapatkan bahwa semua item valid dengan nilai $r$ terendah 0,422 dan tertinggi 0,697 nilai $\mathrm{r}$ tersebut $>$ dari nilai $\mathrm{r}$ tabel=0,361. Nilai uji reliabilitas 0,792 yang menunjukkan reliabel karena nilai alpha cronbach $0,7>a \geq 0,6$. 
Journal of Healthcare Technology and Medicine Vol. 6 No. 1 April 2020

Universitas Ubudiyah Indonesia

e-ISSN : 2615-109X

Ethical Consideration and Data Colletion

This research had been approved by the Committee and Ethics of Faculty of Medicine, University of Diponegoro in Maret 2017. Prior to the data collection, informed consents were obtained from the respondents.

\section{Data Analysis}

Spearman Rank analysis was used to identify the relation between factors that can be modified (Experince,workload, ablity) and unmodified factor (genetic and maritalstatus). Yang mempengaruhi kualitas tindakan mandiri perawat di ruang rawat inap RSUD dr. M. Haulussy Ambon.

\section{HASIL DAN PEMBAHASAN}

Characteristics of the respondents

Tabel 1 menunjukkan bahwa responden terdiri dari jenis kelamin laki-laki 18,8\% dan perempuan $81,2 \%$. Sedangkan untuk yang sudah menikah 92,\% dan belum menikah 7,3\%. Hasil tersebut menunjukkan bahwa sebagian besar perawat yang bekerja di ruang rawat inap didominasi oleh perempuan dan sebagin besar sudah menikah.

\section{Kualitas tindakan mandiri perawat, pengalaman, kemampuan dan beban kerja}

Perawat di ruang rawat inap memiliki nilai rata-rata dalam melakukan tindakan mandiri adalah sebesar $(10,67)$ dengan nilai tertinggi 14 dan terendah 5. Untuk nilai rata-rata pengalaman perawat $(4,42)$ dengan pengalaman tertinggi 30 tahun dan terendah 1 tahun. Beban kerja perawat memiliki bilai rata-rata $(62,15)$ dengan nilai tertinggi 122 dan terendah 6. Sedangkan untuk kemampuan perawat mendapatkan nilai rata-rata $(141,30)$ dengan kemampuan tertinggi 173 dan terendah 106. (lihat Tabel 2)

\section{Deskripsi Kualitas tindakan mandiri perawat, pengalaman, beban kerja dan kemampuan}

Hasil analisa tabel 3 menunjukan bahwa perawat di ruang rawat inap RSUD dr. M. Haulussy ambon melakukan tindakan mandiri keperawatan dengan kategori baik sebesar $55,8 \%$ dan kategori kurang 44,2\%. Pengalaman perawat di ruangan dengan nilai $61,2 \%$ termasuk dalam pengalaman tinggi sedangkan untuk pengalaman rendah dengan nilai 38,8\%. Kemampuan perawat di ruang rawat inap RSUD Dr. M. Haulussy Ambon memiliki nilai 53,3\% termasuk dalam kategori kemampuan baik dan kemampuan kurang dengan nilai 
Journal of Healthcare Technology and Medicine Vol. 6 No. 1 April 2020

Universitas Ubudiyah Indonesia

e-ISSN : 2615-109X

46,7\%. Sedangkan untuk beban kerja dengan nilai 52,7\% termasuk dalam beban kerja tinggi dan $47,3 \%$ termasuk dalam beban kerja rendah. 
Journal of Healthcare Technology and Medicine Vol. 6 No. 1 April 2020

Universitas Ubudiyah Indonesia

e-ISSN : 2615-109X

Tabel.1 Characteristic of the respondents $(n=165)$

\begin{tabular}{|l|c|c|}
\hline Karakteristik Perawat & F & $(\mathbf{\%})$ \\
\hline Jenis Kelamin & & \\
- Laki-laki & 31 & 18,8 \\
- Perempuan & 134 & 81,2 \\
\hline Status Pernikahan & & \\
- Menikah & & \\
- Belum Menikah & 153 & 92,7 \\
& 12 & 7,3 \\
\hline
\end{tabular}

Tabel 2.Kualitas tindakan mandiri perawat, pengalaman, kemampuan dan beban kerja $(n=165)$

\begin{tabular}{|l|c|c|c|c|}
\hline \multicolumn{1}{|c|}{ Variabel } & Mean & Median & S.D & Min-Max \\
\cline { 1 - 4 } $\begin{array}{l}\text { Kualitas Tindakan } \\
\text { Mandiri Perawat }\end{array}$ & 10,67 & 11,00 & 2,625 & $5-14$ \\
\hline $\begin{array}{l}\text { Pengalaman perawat di } \\
\text { ruangan }\end{array}$ & 4,42 & 3,00 & 3,691 & $1-30$ \\
\hline Beban kerja Perawat & 62,15 & 63,00 & 29,598 & $6-122$ \\
\hline Kemampuan Perawat & 141,30 & 140,00 & 10,744 & $106-173$ \\
\hline
\end{tabular}

Tabel 3.Deskripsi Kualitas tindakan mandiri perawat, pengalaman, beban kerja dan kemampuan $(n=165)$

\begin{tabular}{|l|c|c|}
\hline \multicolumn{1}{|c|}{ Variabel } & F & \% \\
\hline Pengalaman Perawat di ruangan & & \\
- Tinggi & 101 & 61,2 \\
- Rendah & 64 & 38,8 \\
\hline Beban kerja Perawat & & \\
- Beban kerja tinggi & 87 & 52,7 \\
- Beban kerja rendah & 78 & 47,3 \\
\hline Kemampuan Perawat & & \\
- Kemampuan baik & 88 & 53,3 \\
- Kemampuan kurang & 77 & 46,7 \\
\hline
\end{tabular}

Tabel. 4 Analisa bivariat antara pengalaman, beban kerja dan kemampuan dengan kualitas tindkana mandiri perawat $(n=165)$

\begin{tabular}{|l|l}
\hline Variabel & Kualitas Tindakan Mandiri Perawat \\
\hline
\end{tabular} 
Journal of Healthcare Technology and Medicine Vol. 6 No. 1 April 2020

Universitas Ubudiyah Indonesia

e-ISSN : 2615-109X

\begin{tabular}{|l|c|c|}
\hline & Koefisien Korelasi & P value \\
\hline Pengalaman Perawat & $\mathrm{r}=0,266$ & 0,001 \\
\hline Beban Kerja Perawat & $\mathrm{r}=0,232$ & 0,003 \\
\hline Kemampuan Perawat & $\mathrm{r}=0,257$ & 0,001 \\
\hline
\end{tabular}

Hasil analisa bivariate pada tabel 4. menunjukkan bahwa terdapat hubungan yang signifikan antara pengalaman, beban kerja dan kemampuan dengan kualitas tindakan mandiri. Keeratan korelasi antara variabel dalam kategori lemah dengan nilai (r) antara 0,1-0,40.

Tabel 5. Analisa Multivariat Multiple Regration

\begin{tabular}{|l|c|c|c|c|c|c|}
\hline \multicolumn{1}{|c|}{ Variabel } & $\begin{array}{c}\text { Koefisien } \\
\text { beta (B) }\end{array}$ & S.E & $\begin{array}{c}\text { Koefisien } \\
\text { Korelasi( } \\
\text { Beta) }\end{array}$ & Sig & R & $\begin{array}{c}P \\
\text { Value }\end{array}$ \\
\cline { 1 - 6 } Pengalaman Perawat & 0.069 & 0.052 & 0.097 & 0.185 & & \\
\cline { 1 - 4 } $\begin{array}{l}\text { Beban Kerja } \\
\text { Perawat }\end{array}$ & 0.014 & 0.006 & 0.006 & 0.011 & \multirow{2}{*}{0.645} & 0.000 \\
\hline Kemampuan & 0.036 & 0.015 & 0.150 & 0.023 & & \\
\hline Constant & -0.965 & 2.539 & -0.380 & 0.704 & & \\
\hline
\end{tabular}

Note: *) significant when $\alpha=0.05$

\section{Faktor yang paling dominan mempengaruhi kualitas tindakan mandiri perawat}

Hasil analisa regresi linear berganda pada tabel 5 didapatkan bahwa semua variabel mempengaruhi kualitas tindakan mandiri perawat. Pengalaman memiliki nilai $(\mathrm{r}=0.097$; CI95\%: 3.85-4,99; $\mathrm{p}=0.185)$. Sedangkan untuk beban kerja ( $\mathrm{r}=0.006 ;$ CI95\%: 57.60-66.70; $\mathrm{p}=0,011)$. Kemampuan perawat miliki nilai $(\mathrm{r}=0.150 ;$ CI95\%:139.65-142.95; $\mathrm{p}=0,023)$. Dari semua variabel yang paling mempengaruhi kualitas tindakna mandiri perawat adalah kemampuan dengan nilai $(\mathrm{r}=0,150)$.

Hasil penelitian mendapatkan bahwa terdapat hubungan antara pengalaman perawat di ruangan dengan tindakan mandiri perawat. Tingginya pengalaman yang didapat oleh perawat di ruang rawat inap RSUD Dr. M .Haulussy Ambon yakni 3 tahun. Dalam jangka waktu tersebut seorang perawat memiliki banyak pengalaman terutama dalam memberikan tindakan kepada pasien berupa melakukan mobilisasi posisi pasien, melakukan verbedent dan membantu memberikan makanan kepada pasien. Banyaknya tindakan yang dilakukan dapat meningkatkan kualitas tindakan mandiri perawat dan akan terlihat perbedaan antara perawat yang memiliki pengalaman dan tidak. Dari hasil penelitian menunjukkan makin 
Journal of Healthcare Technology and Medicine Vol. 6 No. 1 April 2020

Universitas Ubudiyah Indonesia

e-ISSN : 2615-109X

lama tenaga kerja bekerja, makin banyak pengalaman yang dimiliki tenaga kerja yang bersangkutan. ${ }^{18}$ Pengalaman bekerja banyak memberikan keahlian dan keterampilan kerja. Sebaliknya, terbatasnya pengalaman kerja mengakibatkan tingkat keahlian dan keterampilan yang dimiliki makin rendah. ${ }^{19}$ Pengalaman bekerja merupakan modal utama seseorang untuk terjun dalam bidang tertentu.

Hasil penelitian ini sesuai dengan Ami tahun 2016 yang mengatakan bahwa setiap perawat memiliki pengalaman yang berbeda-beda dalam merawat atau memberikan tindakan kepada pasien. ${ }^{20}$ Pengalaman yang berbeda ini yang akan memberikan dampak berbeda pula bagi setiap perawat dalam melakukan tindakan mandiri kepada pasien. Pengalaman juga dapat menentukan sejauh mana perawat itu professional dalam menjalankan tugasnya khususnya dalam memberikan pelayanan kepada pasien. ${ }^{21} \mathrm{Hal}$ ini disebabkan karena perawat memiliki karakteristik dan pengetahuan yang berbeda-beda.

Menurut Ace tahun 2014 bahwa pengalaman berkerja banyak memberikan keahlian dan keterampilan kerja. Sebaliknya, terbatasnya pengalaman kerja mengakibatkan tingkat keahlian dan keterampilan yang dimiliki makin rendah. ${ }^{22,23}$ Pengalaman bekerja yang dimiliki seseorang, kadang-kadang lebih dihargai dari pada tingkat pendidikan yang menjulang tinggi. Pengalaman bekerja merupakan modal utama seseorang untuk terjun dalam bidang tertentu. ${ }^{18,24}$ Oleh karena itu, pengalaman perawat di ruangan harus dipertimbangkan oleh pihak rumah sakit dalam melakukan rekrutan atau merotasi tenaga perawat, karena akan mempengaruhi dalam memberikan tindakan mandiri kepada pasien.

Kualitas tindakan mandiri juga dipengaruhi oleh beban kerja maka semakin berkualitas tindakan mandiri maka beban kerja perawat menjadi menurun. Hasil ini sejalan dengan penelitian yang dilakukan oleh Rista tahun 2016 bahwa terdapat hubungan yang signifikan antara beban kerja dengan kinerja perawat. ${ }^{25,26}$ Menurut Gurses dalam Satria tahun 2013 menyatakan bahwa beban kerja dapat mempengaruhi stress kerja perawat selain itu juga dapat mempengaruhi pelayanan kepada pasien serta keselamatan pasien sehingga kinerja perawat menjadi rendah. ${ }^{27}$ Melakukan tindakan mandiri termasuk salah satu bentuk kinerja perawat di rumah sakit. Kinerja perawat menurun maka akan mempengaruhi kualitas tindakan mandiri yang diberikan. Dampaknya pasien tidak puas dengan pelayanan yang diberikan, selft care pasien menurun serta citra perawat akan menjadi menurun di kalangan pengguna pelayanan kesehatan.

Beban kerja yang berat akan menimbulkan stress kerja pada individu yang pada akhirnya akan mempengaruhi perawat dalam melakukan tindakan mandiri menjadi kurang baik. Sebaliknya beban kerja yang ringan akan menimbulkan kebosanan kerja yang pada 
Journal of Healthcare Technology and Medicine Vol. 6 No. 1 April 2020

Universitas Ubudiyah Indonesia

e-ISSN : 2615-109X

akhirnya juga menyebabkan perawat kurang dalam melakukan tindakan mandiri menjadi.

Beban kerja perawat sangat dipengaruhi oleh jumlah perawat, jumlah pasien dan kondisi pasien. ${ }^{28}$ Beban kerja yang tinggi sangat berhubungan dengan patien safety. ${ }^{29}$ Semakin tinggi beban kerja maka memberikan resiko tinggi untuk perawat dalam memberikan tindakan kepada pasien. ${ }^{30}$ Cara mengurangi beban kerja dengan cara memenuhi jumlah perawat sesuai dengan kebutuhan, pembagaian tugas sesuai dengan proporsi dan mampu menciptakan sistem kerja yang dapat mengurangi usaha dalam bekerja. ${ }^{31}$ Meningkatkan kompetensi perawat dalam melakukan tindakan mandiri untuk efesiensi dan efektifitas jam perawatan juga merupakan salah satau cara untuk manangani beban kerja yang tinggi di ruangan.

Dalam bekerja perawat dituntut untuk mampu dalam memberikan pelayanan yang optimal kepada pasien. Kemampuan itu sendiri terdiri dari dimensi pengetahuan dan keterampilan. Menurut Hersey dan Blanchard kemampuan sendiri terdiri dari tehnical skill, social skill dan conseptual skill. ${ }^{32}$ Kemampuan teknis perawat meliputi; penguasaan perawat terhadap alat-alat kesehatan, prosedur tindakan mandiri serta kewajiban dan tugas-tugas perawat. Sosial skill meliputi; kemampuan bekerjasama dengan tenaga perawat, kemampuan berempati dan bekerja dalam tim. Konseptual skill meliputi;memahami kebijakan, tujuan dan target dari rumah sakit. Ketiga kemampuan ini memiliki peranan yang penting dalam meningkatkan kualitas tindakan mandiri, sehingga perawat dituntut untuk memiliki kemampuan tersebut dalam bekerja.

Kemampuan memiliki hubungan dengan kualitas tindakan mandiri perawat. Hasil penelitian ini sesuai dengan penelitian yang dilakukan oleh Eko Hartanto dalam Listiono tahun 2015 bahwa kemampuan kerja seseorang sangat menentukan kinerja dalam sebuah perusahaan atau organisasi. ${ }^{32}$ Kemampuan merupakan hal yang penting bagi seorang tenaga kesehatan dalam hal ini perawat untuk melakukan dan menyelesaikan tindakan mandiri keperawatan dengan baik.

Kemampuan perawat di ruang rawat inap dalam kategori baik. Hasil ini mengindikasikan bahwa kemampuan yang baik akan meningkatkan tindakan mandiri perawat. Kemampuan yang rendah akan terlihat dari penggunaan waktu dan usaha yang digunakan untuk menyelesaikan tindakan dibandingkan dengan kemampuan perawat yang tinggi. Kemampuan perawat sangat menentukkan kinerja perawat di rumah sakit. ${ }^{32}$ Keberhasilan dan kecakapan pelaksanaan tindakan mandiri di rumah sakit sangat bergantung pada kinerja perawat. Kemampuan perawat merupakan hal yang penting untuk dapat menyelesaikan tugas keperawatan dengan baik. Setiap tindakan yang diberikan 
Journal of Healthcare Technology and Medicine Vol. 6 No. 1 April 2020

Universitas Ubudiyah Indonesia

e-ISSN : 2615-109X

menuntut pengetahuan dan keterampilan dan sikap tertentu agar dapat melaksanakan tugas tersebut dengan optimal.

Kemampuan kerja perawat ditentukkan oleh tinggi rendahnya tingkat pendidikan dan pengalaman. Kedua unsur ini menentukkan pengetahuan dan keterampilan dapat diperoleh. ${ }^{33}$ Jadi semakin tinggi tingkat pendidikan perawat yang ditunjang dengan pengalaman kerja menunjukkan perawat tersebut mempunyai tingkat kemampuan yang tinggi. Kemampuan kerja yang tinggi akan memberikan produktivitas yang tinggi sehingga optimal dalam memberikan tindakan kepada pasien.

Kemampuan perawat dalam meningkatkan kualitas tindakan mandiri menjadi salah satu faktor yang perlu menjadi bahan pertimbangan manajemen rumah sakit untuk dapat meningkatkan kinerja perawat. Hal ini dapat dilakukan dengan mengikuti pelatihan terkait dengan tindakan mandiri perawat. Jika kualitas tindakan mandiri meningkat akan mengurangi angka LOS (Lenght ofStay)pada pasien, meningkatkan patien safety dan meningkatkan self care pasien. ${ }^{34,35}$ Apabila semua komponen tersebut dapat diatasi maka akan menghasilkan pelayanan keperawatan yang paripurna.

\section{KESIMPULAN}

Pengalaman, beban kerja dan kemampuan berhubungan dengan kualitas tindakan mandiri perawat di ruang rawat inap. Faktor yang paling berpengaruh adalah kemampuan perawat.

\section{SARAN}

Saran untuk manajemen RS untuk dapat meningkatkan kemampuan perawat baik dengan cara melanjutkan studi atau mengikuti pelatihan tentang tindakan mandiri. Saran untuk peneliti selanjutnya agar mengambil faktor lain seperti faktor kebijakan dan supervisi.

\section{ACKNOWLEDGEMENT}

The authors acknowledge the Nursing Academy students for being involved in data collection, and thank to all nurse for the participation in this study.

\section{DAFTAR PUSTAKA}

Beth Perry Black. Profesional Nursing, Concepts \& Challeenges. Sounders (Elsivier inc, 2014).

Susanti, E. N. Hubungan Karakteristik Perawat Dengan Motivasi Perawat Dalam Pemenuhan Kebutuhan Kebersihan Diri Pasien Di Ruang Rawat Inap Rsu Dr. H Koesnadi Bondowoso. Univ. Jember (2013).

Chichi Hafifa, T. Faktor-Faktor Yang Berhubungan Dengan Kepuasan Kerja Perawat Pelaksana Di Ruang Rawat Inap Rsup Dr. M Djamil Padang Tahun 2012. Univ. Gadjah Mada 
Journal of Healthcare Technology and Medicine Vol. 6 No. 1 April 2020

Universitas Ubudiyah Indonesia

e-ISSN : 2615-109X

Eriawan, R. D. Hubungan Tingkat Pengetahuan Perawat Dengan Tindakan Keperawatan Pada Pasien Pasca Operasi Dengan 'General Aenesthesia' Di Ruang Pemulihan Ibs Rsd Dr. Soebandi Jember. Univ. Jember (2013).

Lake Eileen T, Hayley D Germack, M. K. V. Missed Nursing Care Is Linked To Patient Satisfaction: A Cross-Sectional Study Of Us Hospitals. J. Cent. Heal. Outcomes Policy Res. (2015).

Dabney, B. W. \& Kalisch, B. Nurse Staffing Levels and Patient-Reported Missed Nursing Care. J. Nurs. Care Qual.30, 306-312 (2015).

Jones TL, Hamilton P, M. N. Unfinished Nursing Care, Missed Care, And Implicitly Rationed Care: State Of The Science Review. Int. J. Nurs. Stud.52, 1121-1137 (2015).

Ball JE, Murrells T, Rafferty AM, Morrow E, G. P. Care left undone' during nursing shifts: associations with workload and perceived quality of care. Natl. Nurs. Res. Unit, Florence Nightingale Sch. Nurs. Midwifery (2013).

Kalisch, B. J. Patient-Reported Missed Nursing Care Correlated With Adverse Events. Am. J. Med. Qual.29, 5415-422 (2014).

Trinkoff, A. M. et al. Nurses' work schedule characteristics, nurse staffing, and patient mortality. Nurs. Res.60, 1-8 (2011).

Novitra, M. Peranan Persepsi Pasien Mengenai Empati Perawat dan Aspek Spritualitas terhadap motivasi sembuh pasien rawat inpap. Univ. Gunadarma (2004).

Lake, E. T., Germack, H. D. \& Viscardi, M. K. Missed nursing care is linked to patient satisfaction: a cross-sectional study of US hospitals. BMJ Qual. Saf. 1-9 (2015). doi:10.1136/bmjqs-2015-003961

Menard, K. I. Collegiality, the Nursing Practice Environment, and Missed Nursing Care. (2014).

Devi, A. Gambaran Persepsi Pasien Tentang Pelaksanaan Pemenuhan Kebutuhan Personal Hygiene Oleh Perawat Di Rsud Ungaran Semarang Tahun 2016. Univ. Diponegoro (2016).

María Guadalupe, M.-M., Catalina, M.-R. \& María Guadalupe, I.-G. Missed Nursing Care in Hospitalized Patients. Aquichán15, 318-328 (2015).

Famella, Sri Wahyu Lelly Hana Setyanti, A. M. The Effect of Work Skill, work Experiences And Attitude Work of Performance of Employees At Tobacco Companies Gagak Hitam Bondowoso Regency. Jur. Manajemen, Fak. Ekon. Univ. Jember (2015).

Bassie, L, M. Kepemimpinan dan Manajemen Keperawatan: Teori dan Aplikasi. (EGC, 2013).

Östlund, A. S., Wadensten, B., Kristofferzon, M. L. \& Häggström, E. Motivational interviewing: Experiences of primary care nurses trained in the method. Nurse Educ. Pract.15, 111-118 (2015).

Maben, J., Adams, M., Peccei, R., Murrells, T. \& Robert, G. 'Poppets and parcels': The links between staff experience of work and acutely ill older peoples' experience of hospital care. Int. J. Older People Nurs. 7, 83-94 (2012).

Koehn, A. R., Ebright, P. R. \& Draucker, C. B. Nurses' experiences with errors in nursing. Nurs. Outlook64, 566-574 (2016).

Ahmad, N. R. Pengaruh Disiplin Kerja Dan Pengalaman Kerja Terhadap Prestasi Kerja Karyawan Pada Departemen Produksi Pt. Leo Agung Raya Semarang. J. Ilmu Manaj. dan Akunt. Terap.3, (2012).

Ace Sudrajat, Suhana Haeriyanto, P. I. Relationship Between Knowledge And Job Experience With Nurse's Ability To Do Triage At The Emergency Room. Junal Keperawatan Vol. 2 No., (2014).

Han, A., Won, J., Kim, O. \& Lee, S. E. Anger Expression Types and Interpersonal Problems in Nurses. Asian Nurs. Res. (Korean. Soc. Nurs. Sci).9, 146-151 (2015). 
Journal of Healthcare Technology and Medicine Vol. 6 No. 1 April 2020

Universitas Ubudiyah Indonesia

e-ISSN : 2615-109X

Yue, P., Wang, L., Liu, C. \& Wu, Y. A qualitative study on experience of nurses caring for patients with delirium in ICUs in China: Barriers, burdens and decision making dilemmas. Int. J. Nurs. Sci.2, 2-8 (2015).

Rista Apriana. faktor-faktor yang mempengaruhi kinerja perawat di rumah sakit. (Diponegoro University, 2016).

Myny, D. et al. Determining a set of measurable and relevant factors affecting nursing workload in the acute care hospital setting: A cross-sectional study. Int. J. Nurs. Stud.49, 427-436 (2012).

Satria, W., Sidin, A. I. \& Noor, N. B. Relation Of Work Load With Nurse Performance In Implementation Of Patient Safety Inpatient In Hasanuddin University Hospital 2013. 111 (2013).

Hendianti, G. N. Gambaran Beban Kerja Perawat Pelaksana Unit Instalasi Gawat Darurat Rumah Sakit Muhammadiyah Bandung. Students e-Journal1, 31 (2012).

Carayon, P. \& Gurses, A. P. Nursing workload and patient safety: A human factors engineering perspective. Patient Saf. Qual. An evidence-based Handb. nurses Vol. 2 203-216 (2008). doi:NBK2657 [bookaccession]

Maria, A., Magalhães, M. De, Maria, C., Agnol, D. \& Marck, P. B. Nursing workload and patient safety - a mixed method study with an ecological restorative approach 1 Debate centered on the association between. 21, 146-154 (2013).

Mastini, P., Suryadhi, N. T. \& Suryani, A. Hubungan Tingkat Pengetahuan, Sikap , Beban Kerja Perawat dengan Kelengkapan Dokumentasi Asuhan Keperawatan di IRNA IGD RSUP Sanglah Denpasar Relationship Between Nurse Knowledge , Attitude , Workloads with Medical Record Completion at the Emergency Unit. 3, 49-53 (2015).

3Listiyono. Hubungan Kemampuan Kerja Dan Komitmen Organisasional Dengan Kinerja Perawat (Survey Pada Perawat Blud Rumah Sakit Umum Daerah Salatiga). Univ. Sebel. Maret Surakarta (2015).

Debbie Nelson. Using the ability model to design and implement a patient care plan. Vet. NurseVol 6, (2015).

Aiken, L. H., Sloane, D. M., Bruyneel, L., Van den Heede, K. \& Sermeus, W. Nurses' reports of working conditions and hospital quality of care in 12 countries in Europe. Int. J. Nurs. Stud.50, 143-153 (2013).

Spetz, J., Fraher, E., Li, Y. \& Bates, T. How Many Nurse Practitioners Provide Primary Care? It Depends On How You Count Them. (2015). doi:10.1177/1077558715579868 